the way for adjusting the difficulties following the revocation of a unilateral contract after the promisee has partly performed to his detriment..$^{62}$ Further a frank recognition of the fact that promises may be enforced without consideration might lead to further modifications of the bargain theory of consideration. ${ }^{6}$

\title{
THE ECONOMIC REGULATION OF AIR TRANSPORT
}

Government regulation of private agencies of transportation has become a part of our national life. Fifty years ago, the first Act to Regulate Commerce ${ }^{x}$ created the Interstate Commerce Commission, which began to regulate the railroads; more recently the jurisdiction of the Commission has been extended to motor carriers; ${ }^{2}$ and now Congress is facing the problem of regulating air transportation. ${ }^{3}$

Barely fifteen years old air transport has grown from an experiment to an industry of national scope. Remarkable technical advance has changed flying from a fool-hardy adventure 4 to a commonplace experience, and with the change has come a tremendous increase in the volume of air traffic.5 But despite this growth the financial condition of the domestic airlines has steadily declined. ${ }^{6}$ Especially since the enactment of the present Air Mail Law have losses been heavy. In I936 the loss totaled \$9Io,000, and in I937 it is estimated at $\$ 3,000,000 .^{7}$ It has been said that of the I20 millions of private capital invested in the air transport industry, more than 60 millions have been lost. ${ }^{8}$

${ }^{62}$ See Fuller and Purdue, op. cit. supra, note I2, at $4 \mathrm{IO}$ et seq.

${ }^{6} 3$ See Report of New York Law Revision Commission 9I et seq. (1936).

I 24 Stat. 379 ( 1887 ), and amendments; 49 U.S.C.A. \$\$ 1-40 (Supp. r937).

$=$ Motor Carrier Act of 1935, 49 Stat. 543 (1935), 49 U.S.C.A. § 3 or (Supp. 1937).

3 For the legislation at present before Congress, see note $6 \mathrm{r}$ infra.

4 With the expansion of flying, both commercial and private, it became apparent as early as 1922 that some kind of governmental regulation was necessary to safeguard the public. Although several progressive states did enact licensing laws and some traffic regulations, they were not very effective, as state lines mean nothing to an airplane.

Constitutional doubts over the power of the federal government to regulate into the air, which seemed quite serious at the time, never got beyond the halls of Congress. The Air Commerce Act, 44 Stat. 468 (1926), 49 U.S.C.A. \& 17 I (Supp. I937), was finally enacted under the commerce clause, on May 20, I926. The act confers upon the Department of Commerce jurisdiction over all civil flying, commercial and private. Created under this authority, the Bureau of Air Commerce promulgates rules for air traffic, safety, the licensing of pilots and equipment, and supervises the airways.

5 See Tables, Annual Report of the Postmaster General, 1936, 29.

${ }^{6}$ See Barney, The Aviation Industry, Appendix 66-67 (1937) for consolidated earnings statement of airlines.

7 See statement of Col. Gorrell, President, Air Transport Assoc. of America, reported in Hearings, Post Office Department, Appropriations Bill, r939, 536.

${ }^{8}$ Ibid. 
The government is intimately connected with the financial condition of the industry since the major airlines today carry the air mail. It is on the basis of mail pay that the present and proposed regulation of the industry is founded. For where the government pays a private carrier for the transportation of mail, some supervision of schedules and facilities should be allowed the Post Office Department. And if the payment is a "subsidy,"9 thorough supervision of the carrier's activities is required in the public interest. In any event, the present air mail system in which the government acts as middleman between the public and the carrier presents an interesting example of government regulation of business.

It should be noted that many of the factors which required government action in the case of rail and highway transport are not present in aviation. The airline is in many ways unique. It has no right of way to build or maintain; ${ }^{\mathrm{xO}}$ its overhead costs are comparatively low. The "natural monopoly" argument, applied to railroads, has little application to airlines because the railroad is and will remain a formidable competitor, ${ }^{\mathrm{Ix}}$ and there is "natural competition" between the airlines at terminal points..$^{12}$

Finally, it must be remembered that the industry is growing so rapidly that legislation adequate now is outmoded in a year. The many cumulative legislative attempts to solve the problem in the brief past are testimony to this.

I

The history of air transport in the United States is the story of the development of the air mail services. The first scheduled flights were the government's experiment in flying the mail. ${ }^{\mathrm{x}}$ Neither Congress nor the Post Office Department ever intended to continue government operation indefinitely, ${ }^{{ }_{14}}$ and by I925, due chiefly to the success of the Post Office Department, ${ }^{15}$ it was believed that flying had developed to the point where it was feasible to offer mail con-

9 For the sense in which these payments are a subsidy, see pp. 485-86 infra.

so The Federal Government has constructed the greater part of the airways, erecting beacons, maintaining secondary landing fields, radio ranges, etc. The airports used by the commercial operators are generally municipal projects. Discussion of the airport problem has been excluded from this paper; it is, however, especially acute at present. Only half a dozen airports in the country are adequate for the new four-motored transports to be put into operation some time this year. See American Aviation (March, I938).

II In r936, the total number of passengers carried by domestic airlines amounted to less than 6 per cent of the number carried by the Pullman Co. Barney, op. cit. supra note 6, at 44 .

${ }^{2}$ I.e., between New York and the West Coast, and New York and Chicago, the three major lines are in direct competition. Cf. Locklin, Economics of Transportation 780-8I (1935).

${ }_{3}$ On May 15, r9r8, between Newark, N.J., and Washington, D.C. The development of the air mail service is well presented in David, The Economics of Air Mail Transportation (1934). See also Johnson, Government Regulation of Transportation Part VI (1938).

${ }_{14}$ David, op. cit. supra note 13 , at 44 .

Is The Post Office Department successfully tackled the problem of night flying which at that time was very dangerous. $I d$. at $3^{6}$. 
tracts to private operators..$^{16}$ Under the authority of the Air Mail Act of I925, the Postmaster General awarded the first contracts for the private carriage of air mail in July of that year..$^{17}$

The dependence of the air mail contractors on mail pay at this time cannot be overemphasized. Revenue from the carriage of passengers and express was negligible and did not cover even the cost of handling. ${ }^{18}$ Not only was the mail pay uncertain, ${ }^{19}$ but the very contracts on which the existence of the operators depended were of short duration..$^{20}$ Pressure for legislative revision brought the Act of $1928^{2 x}$ which authorized a change in the basis of mail carriage from contract to franchise. The "route certificates" to be obtained through negotiation with the Postmaster General allowed a breaking away from short term competitive contracts, assuring the operators of a continued source of revenue from air mail upon which they could build their systems.

It was at this time that a great boom in aviation occurred. With public imagination captured by the idea of commercial flying on a large scale, transport companies sprang up overnight; and, although many of these were purely speculative, the number of airlines in actual operation doubled in $1928 .{ }^{22} \mathrm{In}$ I928, reduction of the postage rates caused an immediate increase in the volume of air mail by almost roo per cent. ${ }^{23}$ Although the contractors found their revenues nearly doubled while operating expenses remained about the same, nearly all of them were also engaged in unprofitable passenger transportation. ${ }^{24}$

The rg28 Act was, however, a failure. The route certificate provision was never effected. Negotiations between the Post Office Department and the contractors dragged on through $\mathrm{I} 929$ and into I 930 . No satisfactory basis could be agreed upon, chiefly because the contractors objected to the existing compensa-

${ }^{26}$ See Rohlfing, National Regulation of Aeronautics I2 (r93 $\mathrm{r}$ ).

${ }^{77} 43$ Stat. 805 (1925), 39 U.S.C.A. $\$ 466$ (I928). More than a year elapsed between the approval of the first Air Mail Act and the inauguration of service over a domestic route. To the first advertisement, on July $15, x_{925}$, there were only nineteen responses, of which only eight could be considered at all. See David, op. cit. supra note $\mathrm{I}_{3}$, at $65 \mathrm{et}$ seq.

${ }^{28}$ Only 5,782 passengers were carried in 1926 by all operators (mail and non-mail); in r 927 , the number was 8,679 .

'9 I.e., dependent entirely on loads; see pp. 480-8I infra.

${ }^{20}$ The length of the contract period was not set out in the Air Mail Law, but, under the Postal Laws, the maximum period was four years, I7 Stat., 315 (I872), 39 U.S.C.A. $\$ 422$ (I928). The first contracts were let on a four year basis. Cf. David, op. cit. supra note $\mathrm{I}_{3}$, at $59 \mathrm{el} \mathrm{seq.}$

${ }^{2 x} 45$ Stat. 594 (1928).

${ }^{22}$ See note 5 supra, and of. David, op. cit. supra note $\mathrm{r}_{3}$, at $8 \mathrm{r}$ et seq.

${ }_{23}$ Mail carried during month of July, I928: 214,575 lbs. Mail carried during month of August, 1928: 419,049 lbs. Annual Report of Postmaster General, I92I, I26.

${ }^{24}$ See note 5 supra; even in 1936 air mail was contributing 35 per cent of the carriers' total revenues. 
tion scheme. ${ }^{25}$ Several of the major contracts which were to have expired early in I929 were extended from time to time by the Postmaster General. ${ }^{26}$

To relieve this situation, on April 29, I930, Congress finally passed the Watres Act. ${ }^{27}$ The Postmaster General was given almost unlimited power over the transportation of air mail, though his jurisdiction was confined to air mail carriers; passenger transportation, as such, was still officially unrecognized. $\mathrm{He}^{28}$ saw in the authority conferred upon him by the Watres Act the means to reorganize the air transport network. ${ }^{29}$ In I930, the country was covered with a network of airlines, most of them small and operating at a loss. ${ }^{30}$ Wasteful duplication of service, where traffic was insufficient to support even one operator, was an evil requiring a remedy which only federal regulation could supply. Consequently the Postmaster General proposed to open new routes, extend old ones, and adjust mail pay on a basis of economic operation of both mail and passenger service.

His first move after the passage of the Watres Act was to call a conference of the air mail contractors and the larger non-mail operators. These conferences were conducted with such secrecy that there is little reliable evidence available for determining exactly what took place. ${ }^{3 \mathrm{I}}$ The results of these conferences are fairly clear, however. Two new transcontinental routes were proposed and advertised. The bids submitted were rather peculiar: two were offered for the middle route, of which the higher was accepted, and the contract for the southern transcontinental was awarded to the only bidder for it. There was undoubtedly a well defined understanding between the contractors and the Post Office Department. Whether this was so serious as to amount to collusion which would vitiate the contracts is a matter of opinion.

Comparatively speaking, air transport prospered under the Watres Act. While a number of the extensions made were not economically justified by the traffic available, ${ }^{32}$ the reorganization of the air routes was helpful to the indus-

25 P. $48 \mathrm{I}$ infra.

${ }^{26}$ These, and other later extensions, were deemed illegal and made one of the grounds for cancellation of the contracts in 1934 . See p. 475 infra.

${ }^{27} 46$ Stat. 259 ( 1930 ). ${ }^{28}$ Walter F. Brown, Postmaster General, x929-1933.

${ }^{29}$ The Postmaster General was authorized to "make any extensions or consolidations of routes which are now or may hereafter be established." This was a carte blanche to revamp the entire air mail map, without competitive bidding. 46 Stat. 259 (I930). Equally important was the clause which authorized the Postmaster General to modify the rates of compensation to a certificate holder. This power was left entirely to the discretion of the executive. $I d$. at $\S 3$.

${ }^{30}$ There were 43 scheduled transport operators in I930; today there are I 7 mail operators. Aircraft Year Book 434 (1937) shows 23 operators in service during the calendar year I936-37. This means that not more than 6 non-mail carriers are included. $C f$. note 5 supra.

${ }^{3 r}$ Hearings, Investigation of Air Mail and Ocean Mail Contracts, 73d Cong. 2d Sess. Parts IV, V, VI, especially pp. $\times 739, \times 794, \times 856$ (I933); and $i d$. at 2349, 24I9, 2479 et seq. (the testimony of Walter $\mathrm{H}$. Brown).

${ }_{32}$ David, op. cit. supra note $\mathrm{I}_{3}$, at $\mathrm{x}_{33}$. 
try in that it allowed the operators to expand as they could without crowding. But there was still considerable dissatisfaction among the carriers, especially those who had not been successful at the "spoils conference" of x930. It was brought to the attention of Congress through an investigation of a House Committee that two transport systems handled almost four fifths of the domestic air mail traffic, and yet received barely one-half of the total pay. ${ }^{33}$ Four operators carried in the aggregate more than 96 per cent of the traffic.

A Senate committee, headed by Senator Black, was even more active in bringing out information which bore on the air mail situation. ${ }^{34}$ And on February 9, I934, Postmaster General Farley, acting on the strength of the findings of the Black committee and on his own private information, issued an order cancelling all domestic air mail contracts as of February 19, I934. ${ }^{35}$ In a letter to the President ${ }^{36}$ and in an open letter to Senator Black, ${ }^{37}$ the Postmaster General explained his action on the grounds that several of the contracts (including two of the transcontinental routes) let under the Act were collusive and contrary to law, and also that the former Postmaster General had illegally extended contracts which were now expired.

On February 19, 1934, by executive fiat, the United States Air Corps took over the job of flying the mail. Lack of experience with transport flying, inadequate equipment, and bad weather contributed to a series of disastrous accidents which are still in the public memory. In the short period of operation, February I9 to May 8, I934, twelve lives were lost; in 66 accidents, the War Department suffered a loss of $\$ 517,599$ in damage to equipment, ${ }^{38}$ and the total cost to the government was $\$ 3,767,355.22 .{ }^{39}$

33 House Report I956, 72d Cong. 2d Sess., 76 Cong. Rec. 3235 (Feb. 2I, I933); see 32 Aviation $177-8$ (June, I933).

${ }^{34}$ The reported hearings of the Black Committee, op. cit. supra note 31 , are contained in four large volumes, and are so detailed as to make difficult even tentative conclusions about the evidence presented.

35 The air mail contractors did what they could to forestall actual cancellation. Transcontinental and Western Air, holder of one of the cross-country routes in question, filed a bill in the Federal District Court for the eastern district of New York, praying that an injunction issue against the Postmaster General restraining him from executing the cancellation. The bill was dismissed for lack of jurisdiction on the rationale that the Federal Government was not subject to suit without its consent. Transcontinental \& Western Air Inc. v. Farley, 7 I F. (2d) 287 (C.C.A. 2d. I934); 33 Aviation 9I (March, I934). Most of the contractors filed damage claims against the government after cancellation had been accomplished. Those suits which have not been compromised at this date are still pending. See I American Aviation for July, Nov., 1937.

${ }^{36}$ N.Y. Times, Feb. ro, x934, p. x, 2.

37 N.Y. Times, Feb. I5, 1934, p. Io.

${ }^{38}$ Aircraft Year Book I 24 (I935).

39 An average cost-per-mile of $\$ 2.2 x$ as compared to a 54 cent per mile average paid to contract carriers for the fiscal year ending June 30, I933. Annual Report of the Postmaster General, r933, appendix. 
Army operation was an emergency measure from its inception, and immediately upon the annulment of the contracts, Congress began to work on new legislation for private carriage. In addition to the proposals for air transport legislation already before Congress, ${ }^{40}$ between February ro and March ro some forty air mail bills were introduced in both houses.

Events of the next few months are so crowded and unexpected that they are confusing even four years thereafter. With the Army Air Corps almost demoralized and with Congress split up into divergent groups, the President wrote to the leaders of the committees most concerned outlining his views on the revision of the air mail laws. The letter was made the basis of the bill, ${ }^{4}$ which after much rewriting and amending, ${ }^{42}$ finally became the Air Mail Law of 1934 on June I2.43

Meanwhile, the emergency had become so acute that an immediate return to private air mail carriage was necessary. On March 28, the Postmaster General announced that advertisement for temporary bids would soon be made.44 No new legislation had come out of Congress, but the proposal was made under a provision of the Postal Laws of 1872 , which authorized the Postmaster General to let temporary contracts for the carriage of mail.45 Such contracts were to be for just go days' duration, but the Postmaster General could extend them, at his discretion, for as much as 9 months. In the interim, the former contractors had maintained their passenger and express service over their old routes..$^{6}$ Service was re-established by the private operators in the early part of May, United Airlines carrying the first transcontinental schedule on May 8.47 These temporary contracts carried over into the fall of I934 by extensions in ac-

${ }^{40}$ The Kelly Bill of 1933 ; see 32 Aviation $177-8$ (June, 1933). The McMillan Bill before and the Mead Bill just after cancellation; see Air Mail Legislation in the Making, 33 Aviation 99 (April, 1934).

${ }^{45}$ S. 3012,78 Cong. Rec. 404x (1934).

${ }_{42}$ An amendment in the nature of a substitute was submitted by Sen. McKellar, S. 3770, 78 Cong. Rec. 5207 ( 1934 ), after a White House conference. The bill finally passed the Senate, after still further amendment on April 28, 78 Cong. Rec. 7629 (1934).

${ }^{43}$ The Senate Bill was sent to the House where it was amended again, and so passed May Io, 78 Cong. Rec. 8556 (1934). But the Senate refused to accept the House revision and a conference was necessary. The hybrid bill which came out of that conference became the Black-

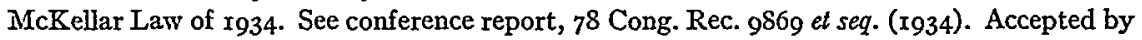
House on May 29, 78 Cong. Rec. 9880 (I934), and by Senate on June 5, 78 Cong. Rec. 1o5r2 (I934).

${ }^{44} 33$ Aviation 153 (May, I934).

4527 Stat. 268 ( 1892 ), 39 U.S.C.A. $\$ 422$ (1928).

${ }_{46}^{43}$ Aviation 92 (March, 1934). In spite of restricted schedules, the number of passengers carried during Febuary, March, April, and May 1934, remained about the same as during the same period of $x_{933}$; the total passenger and express miles flown increased during the same period. Aircraft Year Book 454 (I935).

47 The new air mail map was almost the same as before cancellation: the net change in air mail mileage being an increase of 3,547 miles over the system flown just before cancellation. Annual Report of the Postmaster General, 1934, 25. 33 Aviation I87 (June, 1934). 
cordance with the then existing law, $4^{8}$ until the new Black-McKellar law went into effect on October I.

The present Air Mail Law, enacted as emergency legislation, was an avowed temporary measure.49 The single gesture toward comprehensive treatment of the problem was a provision for the creation of a Federal Aviation Commission which was to study the problem and recommend a permanent program..$^{50}$ The report of this Commission is undoubtedly the most valuable contribution toward solution that has yet been made..$^{5 x}$

The Air Mail Law was essentially what its title indicates. Carriage of mail is paramount; the Postmaster General is given, in effect, absolute power over the development of the industry. ${ }^{52}$ Only holders of air mail contracts are within the provisions of the law. Non-mail operators are entirely without regulation. ${ }^{53}$ Furthermore, expansion of the system is dependent on mail contracts, not only because an operator may be financially unable to undertake a new route without the revenue supplied by air mail, but also because section $15^{54}$ of the Act provides that no air mail contractor may fly "off line"- that is, between any two points not on his air mail route-if such service would "in any way compete" with service "available on another air mail route." As all important cities have some kind of air mail service, it is virtually impossible to initiate a new, secondary route which will not deflect some of the existing traffic from a mail run. The fact that a proposed "off line" route would necessarily deflect present traffic is proof in itself that the new service is desirable in the "public convenience and necessity." Applications for new off line service have been denied by the Interstate Commerce Commission on the ground that the Air Mail Law specifically prohibits such service. 55 T.W.A., denied entrance into San Francisco under section I5, is now operating into that city by virtue of a mail contract for which it is paid at the rate of one mill per airplane mile..$^{6}$ The passenger and

${ }^{8}$ Annual Report of Postmaster General, I935, 22.

49 See letter from the President, March 7, I934, to Sen. McKellar and Rep. Mead, 33 Aviation 99, Ir8 (April, 1934). Sen. McCarran of Nevada did propose economic regulation of air transport by a commission, 78 Cong. Rec. 5384,6454 , 7614 (r934); however, his bill was defeated, 78 Cong. Rec. 7628 (1934).

${ }^{\text {so }} 48$ Stat. 938 (1934), 39 U.S.C.A. $\$ 469$ (r) (Supp. r937).

sx Federal Aviation Commission, Report. Sen. Doc. 15, 74th Cong. Ist Sess. (I935).

52 Although, under the law, the Interstate Commerce Commission is vested with most of the regulatory functions. 48 Stat. 935 (I934), 39 U.S.C.A. $\$ 469$ (d) (Supp. I937).

53 Except safety requirements, etc. See note 4 supra.

${ }^{54} 39$ U.S.C.A. $\$ 469$ (m) (Supp. r937), added by amendment in 1935,49 Stat. 6r9 (r935).

ss Transcontinental and Western Air, San Francisco operation, 220 I.C.C. I63 (r937); noted 47 Yale L. J. 465 ( (1938). Similar applications have been made: Air Mail Docket No. 2I, American Airlines, Inc., Detroit-Cincinnati Operation, and Air Mail Docket No. 22, American Airlines, Inc., Detroit-Indianapolis Operation; hearings have been held, and decisions are pending. Annual Report I.C.C., 1937, 35 .

${ }_{56}$ Transcontinental and Western Air, Air Mail Bid, 223 I.C.C. 28I (1937); Annual Report I.C.C., 1937, 38. T.W.A. was the only bidder for this contract. 
express services, which T.W.A. is required to furnish by the terms of the contract, are no less competitive with services upon other air mail routes because they have the protection of an air mail contract.

In this way, the Post Office Department is able to establish service which is prohibited by another section of the same law. It is unquestioned that the Post Office Department has been in a large way responsible for the development of domestic air transport, ${ }^{57}$ but the industry has now grown beyond the demands of the Postal Service..$^{8}$

It has been proposed ${ }^{59}$ that the existing contract system be discarded and air transport be put on a franchise basis. ${ }^{60}$ Under S. $2{ }^{6 \mathrm{x}}$ air transport would become an integrated part of the national transportation system under the jurisdiction of the Interstate Commerce Commission. ${ }^{6 r a}$ All domestic air carriers, including both the present mail contractors and non-mail operators, would be within the jurisdiction of the Commission. ${ }^{62}$ Upon passage of the Bill, each carrier must apply to the Commission for a "certificate of public convenience and necessity" which entitles it to operate between designated points. The Commission will grant the certificate if it finds (I) that the applicant is able to perform the service proposed, and (2) that such service is or will be required in the public interest. ${ }^{63}$ The present mail contractors, and any other carriers who have been in operation for a reasonable length of time at the date of the passage of the Bill, are entitled to receive a certificate as a matter of right. However,

57 This was recognized by the Howell Comm., op. cit. supra note $5^{\mathrm{r}}$, at 49 .

${ }^{8}$ "During the last four years the airlines have so broadened their function that an air transport system can no longer be planned with primary regard to postal needs. It has to be considered as a purveyor of transportation to the community, and the government's relationship to that line must have equal regard to the interests of the users of mail service, of passengers, and of shippers of express." Ibid.

39 Notably, by Sen. McCarran, note 49 supra. His latest attempt, S. 2, is now before Congress; see note 6 I infra.

${ }^{60}$ The Fed. Aviation Commission, note $5 \mathrm{x}$ supra, recommended the franchise system in I935.

6x $\mathrm{S} .2$, Air Transport Act of 1938 (identical bill in House, H.R. 5234). The Bill is drawn as an amendment to the Act to Regulate Commerce, note I supra, and is closely patterned after the Motor Carrier Act of 1935,49 Stat. 543 (I935), 49 U.S.C.A. § $301-27$ (Supp. 1937). Since the material in this note was written, a new draft of S. 2 has been submitted (March 3, I938, $75^{\text {th }}$ Cong. $3 \mathrm{~d}$ Sess.). The most significant change of the recent amendment is the creation of an "Aviation Authority," $\S 3$ or. The administrative provisions will be discussed infra $\mathrm{p}$. $49 \mathrm{r}$. The proposed inclusion of safety and all other civil aeronautics regulation within the single authority is beyond the scope of this note. On the provisions dealt with herein, the new section numbers will be used.

For brief discussion of old S. 2 see Johnson, op. cit. supra note $\mathrm{I}_{3}$, at 628-32.

${ }^{6} \mathrm{ra}$ Or, as now proposed, the "Aviation Authority."

62. $S .2, \S 3 \operatorname{II}(\mathrm{a})$.

${ }^{63} \S 3 \mathrm{II}(\mathrm{d})$. The Postmaster General and any other interested parties may intervene in the public hearing on such an application. 
no certificate may be issued unless the carrier-applicant agrees to provide for the carriage of mail on such terms as the Postmaster General shall prescribe. ${ }^{64}$ Each certificate shall continue for an indefinite period until revoked or suspended by the Commission for cause. ${ }^{65}$

The requirement of a certificate of convenience and necessity is rather strong medicine for so young an industry as air transport. New entrants into the field are likely to be few in the face of the rigid requirements. Will this make for a monopoly by now existing airlines? It must be noted that under the Bill no exclusive franchise or proprietary right is conferred by a certificate. ${ }^{66}$ Whether or not routes should be paralleled is a matter left entirely to the discretion of the Commission. ${ }^{67}$ However, control of entry into the industry is essential if there is to be any check on uneconomic duplication of service or destructive competition. ${ }^{88}$

II

The most troublesome problem in the development of the air mail service has been the method of compensating the private operators. Fundamentally simple, it is complicated by the admixture of several seemingly extraneous factors. It will be recalled that since the beginning of private air mail operation, the mail carriers have also been engaged in the business of carrying passengers and express. As this latter service has been operated at a considerable loss, it was inevitable that mail pay should bear some of it. Understanding this, Congress was willing to foster the air transport industry, but it balked at the idea of any subsidy. Consequently, in each of the various legislative attempts to solve the problem, Congress tried to make certain that the service would be conducted at no net loss to the government by providing that payments to air mail contractors should not exceed the postal revenues derived from the sale of air mail service to the public.

Obviously, there is no necessary relation between the actual cost of flying the mail (to the operator) and the postal receipts. Much of the postal service

${ }^{64} \$ 3$ II (g). These "terms" however must be "not inconsistent with" the Act.

${ }^{65} \mathrm{And}$ only after full notice and hearing. $\$ 3 \mathrm{rI}(\mathrm{j})$.

One further condition on the holding of a certificate is an agreement by the carrier to abide by the decisions of the National Labor Board in respect to wages, hours, working conditions, and employer-employee relations. $\$ 3 \mathrm{II}(\mathrm{n})(\mathrm{I})$, and Title $\Pi$ of the Railway Labor Act, 49 Stat. rr89 (I936), 45 U.S.C.A. \& I8I-8 (Supp. I937), is also applied to air carriers under the Bill. $\S 3 \operatorname{Ir}(\mathrm{n})(2)$. On the strength of this provision, labor has given the Bill wholehearted support. See testimony of Edward G. Hamilton, Air Line Pilots Assoc., Hearings on S. 2, 75th Cong. Ist Sess. 52 et seq. (I937).

68 \$ 3 Ir (h).

${ }^{67}$ See Fed. Aviation Commission Report, op. cit. supra note 5I, at 55.

${ }^{68} I d$., at 52. Cf. Report of the Federal Coordinator of Transportation, House Doc. 89, 74th Cong. Ist Sess. I2-I3 (r934). The I.C.C. has had bitter experience in dealing with the problem of regulating one agency of transportation while the chief competitor is without its jurisdiction. 
is carried on at a net loss to the department for the benefit of the public. ${ }^{69}$ No one has ever proposed that the carriers fly the mail at less than their own costs; it would be readily conceded that they should be entitled to a reasonable profit in addition to their expenses. But who is to determine what the actual cost of flying the mail is? It is virtually impossible to obtain reliable cost data on air mail alone because all flying costs, for passengers, mail and express, are lumped together and no feasible method of allocation has been yet agreed on. As a protection against a possible unwitting subsidy, then, Congress adopted this "rule of thumb," that payments remain within revenues.

This emphasis on receipts naturally suggests a rate structure built on a weight basis, since postal revenues are computed on a pound scale. The limited load capacity of an airplane makes weight a most important element in air transportation. Thus far, the pound basis of compensation is sound. But distance must be included in the rate base if gross inequities are to be avoided between long and short haul carriers. Also some account should be taken of the type of equipment used, the difficulty of the terrain, prevailing weather conditions, and night flying requirements.

Congressional disposition was made explicit in the first Air Mail Law ${ }^{70}$ which provided simply that the contract rate should not exceed four-fifths of the revenues. However, it was seen that such a scheme would be unreasonably complicated $^{7 x}$ and before any service was begun, the method of compensation was changed to a weight basis, with a top limit calculated to be within the anticipated receipts. ${ }^{72}$ The contractor was to be paid a flat base rate, not to exceed $\$ 3.00$ per pound. This rate applied to the first rooo miles of carriage; each additional roo miles was to add ro per cent to the base rate. This method was defective in that it did not allow sufficiently for the distance factor. Carriers on short routes of two or three hundred miles could be paid the same flat rate as were those on longer hauls, up to rooo miles. This encouraged the establishment of uneconomic short routes. ${ }^{73}$ The longer-haul contractors maintained that the system was unfair to them, not only because of the inequity of the long-short haul compensation, but also because there were no minimum load allowances. Each one was required to fly as much or as little as the Post Office

69 See postal revenues and expenditures, net deficit, Annual Report of the Postmaster General, I934, I22; $i d$. for 1935 , at 131 ; $i d$. for 1936 , at 133 .

${ }^{70} 43$ Stat. 805 (I925). The law gave the Postmaster General the bare power to let contracts for the carriage of air mail. $\$ 4$.

$7 x$ Because of the necessary extra handling and tabulation of each letter. The contractor would be entitled to four-fifths of the postage rate of every piece it carried.

72 The 1926 amendment, 44 Stat. 692 (I926).

73 See David, $o p$. cit. supra note 13 , at 60-64. The great disparity of rates sometimes gave short runs twice or three times as much revenue to the contractor as longer runs: the BostonNewark schedule of 285 miles brought in the maximum of $\$_{3}$ a pound, while the NewarkChicago run of 775 miles brought in only 86 cents. Address of Postmaster General Brown, 4 U.S. Daily 3129, $3{ }^{1} 3^{8}$ (1930). 
Department delivered to him. He was forced to maintain his schedules, and to hope for sufficient mail volume to cover operating costs. Reluctance of the contractors to accept route certificates under the I928 law until a fairer basis of compensation was adopted resulted in the protracted negotiations which later caused so much difficulty. ${ }^{74} \mathrm{~A}$ sympathetic Postmaster General advocated changing the pay unit from pounds to airplane-miles, and allowing for the weight differential by the use of a minimum weight-space..$^{75}$ He suggested a rate base of 30 cents per airplane-mile for the first roo pound unit, with a graduated increase in base rate for every additional roo pounds. The Watres Act incorporated this plan. But as Congress insisted that mail pay have some reference to postal revenues, a top limit of $\$$ r.25 was fixed. ${ }^{6}$

The abandonment of contracts in favor of route certificates under the Watres Act allowed the Postmaster General Brown to use his discretion in devising a rate formula. Although his schedule was awkward in application, the rate structure did take into account most of the factors involved in flying the mail. ${ }^{77}$ It was designed to apply to all air mail routes, with "variables" in the form of additional compensation to adjust the differences between routes. This rate formula effected a marked realignment in the compensation of carriers per mile flown, as a carrier was paid for a minimum weight space per mile whether he carried any mail or not. Meanwhile Congress saw that the $\$ 1.25$ limitation was no limitation at all, and set an arbitrary limit of $x_{5}$ million dollars on air mail appropriations for the fiscal year $1930-31 . .^{78}$

After cancellation, air mail was put back on a contractual basis. The minimum weight-space method of payment was retained in the Air Mail Law of I934, but the rate structure was made much more rigid. Under the present law, air mail compensation is paid at fixed rates per airplane mile, which in no case may exceed a top of $33^{\frac{1}{3}}$ cents. This base rate is increased on a sliding scale of Io per cent for every additional Ioo pound unit carried over the minimum load

${ }^{4}$ P. 474 supra.

75 During the height of the "negotiations" on January I4, 1930, Postmaster General Brown stated, before Cleveland Chamber of Commerce: "The method of determining the compensation of air mail contractors must be revolutionized. . . . The system of paying on the pound regardless of distance travelled is manifestly unsound. Such a system compels the contractor to gamble on the volume of mail he will carry and creates an inducement for him to swell his volume by unethical practices. He is obliged to make his flight whether the Post Office Department furnishes him with one pound or a thousand pounds of mail and he should therefore be paid a just compensation for his readiness to serve, as well as for his service performed." 4 U.S. Daily 3154 (1930).

${ }^{6}{ }_{46} 6$ Stat. I (I930).

77 See Annual Report of the Postmaster General, I93I, I26.

${ }^{88}$ Revenues allocated to sale of stamps for air mail are shown at $\$ 6,210,344.86$ for that year. This gives a deficit of something over Io million. Id. at I08, I25. Again Congress showed its disposition toward mail pay. The next year the appropriation was increased to about 20 million dollars, but this did not help equalize the mail pay as the expansion of service absorbed the increase and more. 
of 300 pounds. But regardless of the amount of mail carried, no rate may exceed the limit of 40 cents per airplane-mile. ${ }^{79}$

The original contract rates are the result of competitive bidding. After the initial period of three years, the Interstate Commerce Commission is directed to review such rates and to adjust them upon a reasonable basis. ${ }^{80}$ While the contract rates are flat rates, the Commission's rates are related to average monthly mileages and are scaled to fluctuate with the changes in the frequency of service required from time to time by the Postmaster General. ${ }^{8 x}$

Along with the increase in passenger and express traffic, the air mail service has grown both in volume and in extent of the system. With greater use of air mail by the public, the postal revenues have increased while total payments to operators have tended to decrease. Once the largest contributor to airline revenues, air mail today supplies only about 30 per cent of the total income. ${ }^{82}$ In I937, the postal receipts attributable to air mail almost equalled the outgo to contractors, making the service practically self-supporting. This does not include, however, the incidental handling and administrative costs of the Post Office Department. For the last fiscal year the total air mail revenues are given as $\$ I 2,439,579$, while total expenditures were $\$ I 9$, I 77, I 29 , of which $\$ I 2,900,000$ was payment to carriers. ${ }^{83}$ This places the allocated costs of the Post Office Department a little over six millions. However, it is not known just how the Post Office Department computes its revenues. If from the sale of air-mail-stamps alone, the estimate is obviously much too low. If from the total weight of mail dispatched, measured by an estimated average revenue per pound, it is hardly more than a reasonable guess. Equally tentative are the expenses allocated to handling and administration. An error of less than I per cent in allotment will cause the assigned cost of air mail to fluctuate as much as six million dollars. ${ }^{84}$

The Post Office statistics assume considerable importance in view of the present Air Mail Law. The Interstate Commerce Commission is directed to adjust the rates of mail compensation so that, by July $\mathrm{I}, \mathrm{I} 938$, the aggregate cost of transportation of air mail does not exceed the anticipated postal receipts therefrom. ${ }^{85}$ While the Post Office Department concedes, really, that its re-

${ }^{79} 39$ U.S.C.A. $\$ 469$ (a) (Supp. 1937).

${ }^{80} \mathrm{Id}$. $\S 469$ (d), as amended I935. The commission has the power to either lower or raise rates, within the statutory limit. The adjustment may be made, after public hearing, only after the expiration of the original contract period (three years). Redetermination of rates have been made by the commission in the following cases: Air Mail Compensation, 206 I.C.C. 675 (I935); 216 I.C.C. I66 (I936); 220 I.C.C. I49 (I936); 222 İ.C.C. 749 (1937); Air Mail Rates for American Airlines, Inc., 225 I.C.C. 12 (1937).

${ }^{8 x} 206$ I.C.C. 675,725 (1935). Cf. testimony of Mr. Haley, Director of Air Mail, I.C.C., Hearings on H.R. 5234, 28.

82 Barney, op. cit. sicpra note 6 , at 45 .

${ }_{83}$ Annual Report of the Postmaster General, ×936, 106.

84 I American Aviation, I-2 (Jan. 7, I938); id., 8 (Feb. I5, I938).

${ }^{85} 49$ Stat. 616 (I935), 39 U.S.C.A. § $469 d($ e) (Supp. 1937), amendment of 1935 . 
ceipts are equal to payments to the carriers, if by "cost," the Commission decides that the total allocated costs of the entire air mail service is meant, ${ }^{86}$ then the commission must reduce present payments by almost one-third.

As a result of the increased volume of air mail and the peculiar provisions of the air mail law, some of the larger operators are actually carrying mail without any compensation whatever. Most airline operators maintain non-mail schedules over their mail routes for the accommodation of passengers. This may be due to the fact that the schedules required by the Post Office Department are too few to accommodate the passenger traffic, or the departures and arrivals are established for mail purposes and are not timely for passenger use. The Post Office Department has contracted to pay for only the "mail schedules." However, the 1935 amendment ${ }^{87}$ authorized the carriage of mail on non-pay schedules, so called "credit trips." All mail carried on these trips is added to the total monthly poundage and included in the computation of the average trip load on which the rate base is founded. This method is obviously to the advantage of both the Post Office Department, which gets the benefit of many more schedules, and of the carrier who is thus able to build up his poundage and boost his base rate into a higher bracket. But, ultimately, because of the arbitrary top of 40 cent limit on mail pay, each route will reach a "saturation point." This has already occurred on Air Mail Routes One and Seven. ${ }^{88}$ Consequently, all mail carried over and above the average which entitles the operator to 40 cents is carried "free."

Under the law as it is, there is only one way open to correct this defect in the rate structure. The Post Office could award the carrier additional pay schedule over the heavy traffic route and in that way increase the total authorized miles for which compensation may be received. The difficulty with this method of relief is that the air mail net work has already reached its statutory limit; the Post Office Department cannot increase or expand the mail system. It is this statutory ${ }^{89}$ limit of 35,000 route miles and the $52,000,000$ annual flown mile limit which is responsible for the "freezing" of the present air mail system. Four contracts let in 1937 added $I 766$ route miles to the system. This brought the total route miles up to within 9 miles of the statutory limit. ${ }^{\circ}$ The recent increase of route and annual flown miles ${ }^{9 x}$ will relieve the tension temporarily at least.

${ }^{86}$ One possible argument for a lenient construction is found in the annual reports of the Postmaster General. Included in the appendices of those reports are tables entitled "cost of air mail service." The "costs" shown are the total payments to the carriers, and nothing more. See Annual Report of Postmaster General, I935, I25; id. for I936, at I28; id. for I937, at 132.

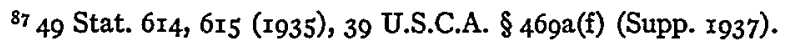

${ }^{88}$ Hearings on S. 2, 75th Cong. Ist Sess. 274 (1937).

89 Note 87 supra.

${ }^{\circ}$ Hearings on Post Office Department Appropriations Bill, I939, 75th Cong. 3rd Sess. I65 (r937).

${ }^{9 x}$ Jan. 15 , r938. (Public No. 240), 83 Cong. Rec. I66, 87 (1938). 
But even those carriers who are not now receiving the top rate may contend that the compensation formula is unfair to them. Most of the present rate bases were fixed by the Interstate Commerce Commission in I935, on the basis of service then, and about to be, performed. Since that time the Postmaster General has revised his requirements by shifting, adding, and discontinuing schedules to such a degree that the 1935 determination is now obsolete. The Commission recognizes this and several rehearings have been had on behalf of the carriers, with consequent adjustment of the rate base. ${ }^{92}$

A recent case ${ }^{93}$ before the United States Supreme Court has brought into issue the character of the Interstate Commerce Commission's power to fix the rates of compensation for the carriage of mail by rail. It was contended by the representatives of the Georgia Railway that the Commission was not acting in a legislative capacity of regulating ordinary freight and passenger rates, but rather as an agent of the government (i.e., the Post Office Department) in a quasi-judicial capacity like a court in an eminent domain proceeding, and that consequently, the railway was entitled to judicial review of both facts and the law. While the Court refused to consider the case on the merits, the case does bring into relief the nature of the Commission's power to deal with mail pay. If there is anything to the eminent domain analogy and the Commission is required to fix rates (reasonable from a confiscation point of view), then the legality of the statutory limitation on air mail rates is at least questionable.

The Lea-McCarran Bill treats air mail compensation from precisely this fair return point of view. Under it, the Commission has full, unrestricted power to fix the rates for mail carriage according to the need of the individual carrier for sufficient revenue, and the need of the nation for an efficient air transport industry. With its power to regulate rates for the transportation of passengers and express, 94 as well as its ability to determine what the government shall pay for its mail service, the Commission will have control over all the revenues of the carriers. The allocation of costs of air transport in fixing passenger and express fares, on one hand, and mail pay, on the other, will be a difficult task. The whole tenor of the Bill points toward the relief of the carriers from their present financial difficulties. 95 This means that total operating costs, where they are reasonable and justified in the public interest, must be considered. The carriers will be allowed to receive a reasonable return on the private capital invested, in accordance with traditional public utility economics. As the airlines have been unable, so far, to cover current operating costs with passenger and express revenues, and as the substantial aid of mail pay, as it is today, has been in-

${ }_{92}$ Annual Report, I.C.C., I936, 3x. For recent rate adjustments, see note 80 supra, especially 225 I.C.C. I2 (T937).

${ }_{93}$ United States v. Griffen, U.S. Law Week (March I, 1938). See discussion of appellee's argument in 6r Traffic World, Ir2 ( 1938 ).

$94 \S 317$. The need of the carrier for revenue sufficient to maintain adequate service, and the need of the nation for an efficient air transport system ( $\$ 30 \mathrm{O}$ ).

${ }^{95}$ See Declaration of Policy, $\S$ I. 
sufficient to allow any profits, compensation for the carriage of air mail must be raised to cover this deficit.

But payment on such a basis smacks of subsidy. An outright grant of money to private industry by the state has always been contrary to American ideals and the economic philosophy on which our industrial structure was built. Although there has long been an indirect subsidation to domestic manufacture in the protective tariff, and direct gifts to the merchant marine, as both measures affected foreign commerce chiefly, they are not so clearly within the ban. If the proposed air transport legislation actually authorizes a subsidy to the private carriers, it must be condemned..$^{96}$

Due to the "luxury" character of air transportation, the national need for it is not so easily established. Why should the Federal government support an industry at the expense of the nation for the benefit of 200,000 persons, who are at the top of the economic pyramid? While the transportation of passengers by air may suffer some from this argument, it is suggested that air mail has become today an important part of our national life. Speed of communication via air mail gives more to the citizen in the lower bracket than to his wealthy neighbor, as the latter can afford other means of rapid communication. Air mail has become a necessity, but that fact alone should not justify a subsidy.

During the early years of railroad building, the Federal government made huge grants of land to the carriers. ${ }^{97}$ This was not thought of as a subsidy, partly because a right of way over the public domain was necessary for construction, and partly because railroading in the United States has always been affected with a public interest. The Federal government has likewise contributed much to the advancement of aviation in building federal airways and improving airports. 98

Traditionally, a subsidy is the amount given by the state to a private industry over and above what that industry could earn in a freely competitive economy. How is this applied to air mail compensation? Congress has applied it by considering the amount of postal receipts attributable to air mail as the maximum amount which would be earned, and the subsidy, therefore, as any amount paid to the contractors for their services which exceeds the amount of the receipts. This interpretation is fallacious. There is no way to determine what might be earned by the air carriers in purely private carriage of the mail by selling service directly to the public, for it has never been attempted, and, under the postal system, it never can be. Secondly, the arbitrary price fixed by Congress which the public must pay for the use of the air mail service has no direct or necessary relation either to the value of that service to the user, or to the costs of the carriers. If the costs of the carriers exceed the price charged the public (and today they very likely do) then the subsidy is to the users of the service. It has been contended that the air mail subsidy is the difference be-

${ }^{96}$ Unless the grant can be justified solely on the ground of national defense.

97 Ripley, Railroads (I917).

${ }^{98}$ Note ro supra. 
tween the amount paid by the government for the transportation of mail and the price of carrying an equal amount of regular air express. ${ }^{99}$ However, this position assumes and ignores too much. The price of air mail cannot be related to the price of carrying an ordinary commodity for reasons outlined above; and such an assumption certainly ignores the singular preferential treatment which air mail receives today..$^{100}$

The only meaningful use of the term subsidy as applied to air mail compensation is the direct relation between the costs of the carriers in carrying the mail, and the cost to the government in the form of payments to the carriers. The carriers are entitled to the reasonable and necessary costs of operation of the air mail service plus a fair return on the use of their equipment, and no more. Any amount over this paid to the carriers may fairly be termed a subsidy.

However, to isolate the problem does not solve it. The manner of determining the costs of operation of air transport is a difficult task, ${ }^{\text {rox }}$ and the method of allocating those costs, once determined, to air mail operation alone, even more so. It was seen how many variable costs there may be in the operation over a single route. No uniform system of accounts has yet been established, though the new law is certain to include a provision requiring such a system. ${ }^{\mathrm{x} 02}$ When it comes to deciding what proportion of operating costs (and other costs too) should be charged up to the mail service, the conflict between the Post Office Department and the carriers becomes acute. The government emphasizes the volume of mail carried, small in comparison with the poundage volume of passengers and express; the carriers maintain that the rigid maintenance of mail schedules regardless of other traffic is the source of heavy operating losses which the mail service must bear. ${ }^{\mathrm{T} 3}$ Nevertheless, the costs allocation system, it is submitted, is the best answer to the problem. The railroads have been carrying mail on this basis since rgr6 and it seems to work fairly for all concerned. ${ }^{\text {ro4 }}$

The difficulties of administration of mail pay present an entirely different problem-"The rates so fixed and determined shall be paid by the Postmaster General from appropriations for the transportation of mail by aircraft."'ros

If this provision is construed as a mandatory direction, the relation between compensation and mail revenues is completely lost. The Post Office Department will find itself in the unhappy position of appropriating and paying out money at the direction of another agency. This may easily develop into a serious quarrel as there is already open antagonism between the Post Office Department and the Interstate Commerce Commission on the air mail problem. ${ }^{106}$

\footnotetext{
99 American Aviation (Feb. 15, 1938).

${ }^{100}$ Barney, op. cit. supre note 6 , at 47 . ror P. 480 supra. ${ }^{102}$ See note 125 infra.

${ }^{\text {ros }}$ Barney, loc. cit. supra note 100.

${ }^{204}$ See Railway Mail Pay, 144 I.C.C. 675 (I928); 2I4 I.C.C. 66 (I936).

$105 \$ 317$.
}

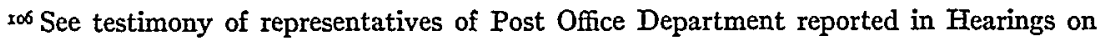
S. 2, op. cit. supra note 65, and on Post Office Appropriations Bill, 1939, op. cit. supra note 90; and of. remarks of Sen. McKellar on floor of the Senate, 8I Cong. Rec. Ir 495 (r937). 
The Commission, acting in perfectly good faith, may fix the rates of compensation in such a way as to shift a disproportionate burden of total operating costs to the carriage of the mail.

While the natural inclination of a governmental agency to pay out as little as possible in actual subsidy to private industry should tend to shift the burden of the cost of air transportation to traffic other than air mail, the fact that not the regulative agency, but another is actually dispensing that subsidy (via mail pay), will temper this inclination. A more straightforward method of handling this problem is to place the responsibility directly on the Congress, who would act with full knowledge and on the recommendations of the chief administrative body. It is submitted that with the advent of thoroughgoing Commission regulation, such as presented in S. 2, the carriage of air mail should be put on a commodity basis along with other kinds of property transportation. ${ }^{107}$ Air mail should have preference over other cargo, but the interests of passenger transportation should not be subordinated to mail. A frank poundmileage rate structure based on an equitable division of pay-load capacity will adequately compensate the carriers and will provide service to the government at a minimum cost. In addition, any deficit from total operations should be paid by a direct appropriation, after a careful investigation by the Commission. ${ }^{\text {xo }}$

\section{III}

The present air mail law is admirably clear on one provision at least. Congress was agreed that the unhealthy conditions of air transport which existed before cancellation should never return. While injurious duplication of service is prohibited by the stringent section $\mathrm{r}_{5},{ }^{\mathrm{1} 09}$ real competition and independence of the carriers is highly to be desired. Therefore, all aviation interests (all persons engaged in the aircraft industry generally) except bona fide air transport companies are barred from the carriage of air mail. ${ }^{\text {xro }}$ Holding companies, interlocking directorates between air transport and other transportation or air manufacturing companies are outlawed, and no executive of an air mail contractor may receive more than $\$ 17,500$ in any form as remuneration from all sources.

S. 2 provides for a considerable relaxation from the strictness of the present law. Ix It is framed in language quite similar to that of the law pertaining to rail and motor carriers. ${ }^{112}$ While the use of holding companies, interlocking directorates and voting trusts as devices to control two air carriers is expressly prohibited, the Commission may authorize such a combination if it believes

${ }^{r 07}$ But $o f$. Report, op. cit. supra note $5 \mathbf{I}$, at 64 . The Commission suggests a uniform flat payment per pound mile for all carriers.

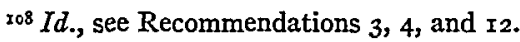

${ }^{\text {rog }} 48$ Stat. 938 (1934), 39 U.S.C.A. $\$ 469 \mathrm{~m}$ (Supp. I937)،

זro 48 Stat. 936, (1934), 39 U.S.C.A. § 469e (Supp. r937). $\quad$ xr $\$ 318$.

זxa Rail, 49 U.S.C.A. $\S 5$ (Supp. I937); motor, id., § 313 (Supp. 1937). 
the best interests of the industry and public will be served thereby. Opponents of Commission regulation maintain that this provision opens wide the door to combinations and monopolies.

Air carriers are specifically relieved from the operation of all anti-trust laws, state and federal-"insofar as it may be necessary to enable them to do anything authorized" by the Commission.113 Any form of combination or agreement, such as consolidation, leasing or pooling arrangements which under the present law "are in restraint of trade," may be lawful if and when the Commission approves and authorizes such action..$^{\mathrm{II}}$

The breadth of the terms of S. 2 gives almost unlimited discretion to the Commission to regulate air carriers. ${ }^{\mathrm{Ir} 5}$ The extent of the air transport system and the service requirements are left to its judgment entirely. This includes the duty "to specify that an air carrier must provide general transportation service which, in the opinion of the Commission, shall be adequate for the public convenience and necessity. ${ }^{\mathrm{x} i}$

This seems to include frequency of service, the times of departure and arrivals, and determination of intermediate stops. ${ }^{\mathrm{II}}$ If the Commission's author-

${ }^{x_{3}} \S 3 \times 8$. This may be done by the commission only if, after a public hearing, it finds that the proposed transaction will be "consistent with the public interest." On this vague grant there are two other restrictions (similarly vague). § 3I8(a)r. No transaction may be approved which would "result in creating a monopoly .... and thereby unduly restrain competition" or "unreasonably jeopardize" another carrier not a party to the proposed action. The same general restrictions are placed on the acquisition of an air carrier by carriers other than air carriers or by persons engaged in the aircraft industry generally. The new draft extends the jurisdiction of the Authority to "persons engaged in the manufacture of aircraft."? $\S 302$. Even after the Jones and Laughlin case, this is a rather striking provision. ·

${ }^{314}$ The need for a more flexible law on consolidations is shown by a recent experience of two operators. United Airlines flies the direct route from Newark to San Francisco via Chicago and Salt Lake City. It also has a coast-wise route from San Diego to Seattle which connects Los Angeles with San Francisco, but no direct route into Los Angeles from the East. Western Air Express, formerly a part of the United Aircraft organization has one, comparatively short route from Great Falls to Los Angeles via Salt Lake City. A leasing agreement was made between United Airlines and Western Air Express whereby a through transcontinental sleeper service into Los Angeles was to be flown by turning over one of United Airlines sleeper planes to Western Air Express at Salt Lake City. This would eliminate the necessity for passengers to change planes in the early morning hours and would permit United Airlines to sell overnight transcontinental service into Los Angeles equal to that of the other two services of American Airlines and Transcontinental and Western Airlines, and also to stimulate traffic over Western Air Express' route. This agreement was disapproved by the solicitor for the Post Office Department on the grounds that such an agreement was contrary to the Air Mail Law. Aug. 28, I937. American Aviation (Sept. I, 1937).

Ixs $\S \S \mathrm{I}, 30 \mathrm{r}$.

${ }^{116}$ Formerly $\S 304(\mathrm{a})(8)$; now $\S 3$ II Ie.

${ }^{x y} 7$ The power of the Commission over schedules under this section is denied by Col. Gorrell. See Hearings on S. 2, op. cit. supra note 65 , at $43^{6}$. He insists that $\S 305(8)$ (old bill), requires the carriers to adjust schedules to the wishes of the Post Office Department. 
ity is construed this broadly, the Bill goes further than any law regulating railroads or busses. Under the present law, air mail schedules are regulated by the Post Office Department, and to some degree by the Bureau of Air Commerce. The carrier, however, retains the power to change his non-mail schedules and the frequency of his service within a wide range of discretion. The departure times are limited by the safety requirements of the Bureau of Air Commerce and somewhat by the needs of the Postal Service.

An increase in the number of passengers schedules when not warranted by traffic may not be only harmful to the carrier because of resulting operating losses, but may be a form of unfair competition with other carriers. It has been pointed out that the only real competition among air carriers is between terminal points such as New York and the West Coast and New York and Chicago. At such points each carrier tries to operate on schedules most popular with the public. Consequently, the departures and arrivals of the competitors are bunched in such a way that there may be three or more departures for a point within a half-hour, and not another trip for several hours. This is not to the best interests of the traveling public. Commission control of non-mail schedules would correct this condition by spacing the rival trips in such a way that a traveler will find a convenient departure at any hour of the day.

The demands of the Post Office Department that it retain control over mail schedules ${ }^{x 8}$ are sound so long as the air mail service remains any considerable justification for Federal support of the industry. Until the industry is able to stand alone, without external support, the mail service, it is submitted, will continue to be the primary reason for governmental aid. While the power of the Commission to fix the rates of mail pay is not unnatural, in view of its long experience with rail mail pay, the Post Office Department should have the fullest control over how and when the air mail is to be dispatched. Congress should make this explicit. ${ }^{118 a}$

The Commission is also to be given full power over the rates for carriage of persons and property. ${ }^{\mathrm{II} 9}$ In some ways, this is the most important section of the Bill. There is, at present, no regulation of passenger and express tariffs,

${ }^{118}$ I.e., specifying departures and arrivals, as contrasted with the right simply to place mail on planes when and if flown.

218a The new Bill does so: $\S 3$ r6(c) gives to the Postmaster General authority over schedules. However, the suitability of the schedules fixed is to be considered in fixing the rates for mail compensation.

Irg $\S 3$ I4. The sections of the Bill which set out the Commission's power over rates ( $\$ \S 3 \mathrm{I}_{4}$ 15) are substantially the same as the provisions of the Transportation Act of 1930 (railroads) and the Motor Carrier Act of 1935 . See testimony of Comm'r. Eastman, Hearings on S. 2, op. cit. sitpra note 65 , at 65 et seq. The Commission is directed to establish reasonable rates for the transportation of passengers and express by air, but it is urged to give "due consideration" to the fact that air transport is a quasi-public utility, that air service is necessary and desirable, and that it needs encouragement. $\S 3 \mathrm{ro}$ (d) (old bill). These provisions do not seem to appear in the latest draft. 
and the airlines are free to cut fares, or offer free transportation as they choose. ${ }^{20}$ Although rate wars have not been a serious factor thus far, the winter of I937- $^{-}$ I938 has seen the institution of some practices which may easily become harmful to the industry. ${ }^{12 \pi}$ As traffic by air is literally seasonal, due to weather conditions, several airlines have greatly reduced their fares for winter travel; this has been justified on the ground of "educating" the travelling public. ${ }^{122}$ The demand for air transportation is highly elastic, so when one airline reduces its fares, the others must follow suit or suffer marked reduction in traffic. A real rate war would ruin the airlines in a short time.

While a rate war is obviously injurious to the carriers, it is not so clearly harmful to the consumer as were the discriminatory practices of early railroading. ${ }^{123}$ Air travel has been branded as "luxury" transportation, and it is difficult to become aroused over discriminations between the wealthiest members of the community. This, however, is an increasingly false conception of air travel today. The average air passenger is a business man, who travels by air because speed is essential to him. As a customer, he is entitled to be treated on a parity with other customers; flying expense is a charge on his business. So far, air transport has been remarkably free from this kind of price discrimination; only in the issuance of non-revenue passes has this particular evil appeared.

However, with steadily growing traffic and increasing competition between the air carriers themselves, some kind of rate regulation is needed. The same evils of rate wars, rebates, and price discriminations which were so prevalent in early railroading are almost certain to appear in an unregulated air transport industry when competitive conditions become acute. The Interstate Commerce Commission has recently asked for jurisdiction over the entire rate structure of the airlines. ${ }^{124}$ Its long experience in rate making and control is a strong argument in favor of such an extension of jurisdiction.

The quasi-public nature of any national transportation system requires more thoroughgoing regulation than does private industry. Publicity of all relevant data, and the uniformity of accounting systems are well known in the public utility field. The present law directs the Interstate Commerce Commission to make examinations of all books, records and accounts of the carriers, but no

${ }^{120} \S_{3_{5}}$ (b) prohibits all free transportation by air carriers except in the cases of employees, their immediate families, and certain others on company business. Railroads and buses are now strictly regulated in granting free transportation. 49 U.S.C.A. $\S I(7) ; \S 3 I 7$ (b).

${ }^{12 x}$ See American Aviation (Feb. I, I938).

${ }_{122}$ Northwest Airlines reduced the fare between Chicago and the Twin Cities from $\$ 15$ one way to \$1 5 round trip. T.W.A.'s "excursion rates" offer round trip passage anywhere on its system for $\mathrm{r} \frac{1}{2}$ of the one way fare. These reductions bring the air fare well under the cost of first class rail travel. The latest promotion (United, American and T.W.A.) is an offer to "wives of flying husbands" to ride along free!

${ }^{123}$ See Ripley, Railroads (I9 7 ).

ז24 Annual Report I.C.C., 1936, 3x-32; id. for 1937 , at 35 et seq. 
power is given to require reports or to prescribe a uniform accounting system. ${ }^{\mathbf{1 2 5}}$ S. 2 provides, however, that the Commission shall have access to all property of carriers (Including documents, correspondence, etc.), and may require regular reports in a specified form. ${ }^{126}$ Complete control over carriers' accounts requires the commission to prescribe "classes of property for which depreciation charges may properly be included under operating charges, and the rate of depreciation which shall be charged." This is particularly important in air transport on account of the short life of transport airplanes. This is not so much because an airplane "wears out," as it is that engineering improvements are so rapid that an airplane is obsolete in a few years. The present Douglas transports, put into service last year, are being written off the airlines' books in four years. This is a depreciation charge of about $\$ 25,000$ per year per airplane.

In making new security flotations, air carriers are made subject to the same regulation as are rail and bus carriers, under S. $2 .^{128}$ Does this imply exemption from the requirements of the Securities Act of $1933^{\text {?29 }}$ Other regulatory provisions of the Bill are identical with the law pertaining to rail carriers. ${ }^{130}$

\section{IV}

The final problem of air transport regulation now facing Congress is one of administration. The earliest controversy over aviation in Congress was on the administration of the Air Commerce Act of 1926 . After doubts concerning the federal power to regulate aviation had been resolved and it was agreed that military and civil flying should be separately controlled, there remained the problem of setting up the administrative body and the promulgation of necessary rules. The difficulties attendant on the creation of a new agency, particularly when it was not any too clear what its functions would be, caused Congress to turn the job over to an already existing body: the Department of Commerce.

If the patchwork nature of the present Air Mail Law were not enough to require new regulatory legislation, the present tri-partite division of authority ${ }^{\mathbf{3}}{ }^{\mathrm{x}}$ over carriers should make the need for reform imperative. One central authority should consider and control all branches of air transportation. There is prac-

${ }_{225} 48$ Stat. 936 (1934), 39 U.S.C.A. $\$ 469$ d and h (Supp. I937).

${ }^{226} \S 3 \mathrm{I} 3$.

${ }^{2} 273_{3} I_{3}(\mathrm{~d})$.

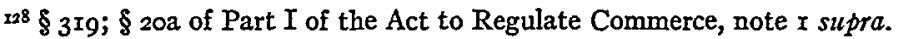

${ }^{229} \mathrm{An}$ interesting innovation of S. $2, \S 3 \mathrm{I} 8(\mathrm{~b}) \mathrm{x}$, declares that it is unlawful for any officer or director of an air carrier ".... to receive for his own benefit, directly or indirectly, any money or thing of value in respect of negotiation, hypothecation, or sale of any securities issued . . . . by such carrier, or to share in the proceeds thereof." This is aimed, evidently, at the private banker or promoter members of the board of directors of an air carrier.

${ }^{{ }^{30}}$ See especially, $\$ \S 375,40 \mathrm{r}$ et seq. and of. Part I $\S \S 6,20$, 20a, Part II $\S \S 317,320,3{ }_{4}$

${ }^{23}$ The Bureau of Air Commerce, the Post Office Department and the I.C.C. 
tical agreement in Congress today that economic regulation by a commission is now needed. But whether such a commission shall be an independent body, or a subdivision of the Interstate Commerce Commission is a question on which there is still a sharp division of opinion.

The Howell Commission proposed the creation of an independent, nonpartisan commission to regulate all civil aeronautics. ${ }^{\mathbf{3 2} 2}$ It was believed that speed of regulatory action was essential in dealing with an art that undergoes such constant and rapid change. For this reason, the Interstate Commerce Commission was thought to be not suitable for aviation because that body already had duties of a "pressing and arduous nature." The Howell Commission also stated that it was of utmost importance "that the fundamental doctrine relative to commission control of aviation and to the allocation of direct aids by commission decision should be developed without becoming involved with the troubles of other forms of transport." 133 The report made clear, however, that a legislative body was to be preferred to a commission answerable only to the executive. ${ }^{334}$

President Roosevelt was unable to agree with the recommendation for a separate regulatory body. In his letter of transmittal to Congress, he stated, "I believe that we should avoid the multiplication of separate regulatory agencies in the field of transportation. Therefore, in the interim before a permanent consolidated agency is created or designated over transportation as a whole, a division of the Interstate Commerce Commission can well serve the needs of air transportation." ${ }_{353}$

Senator McCarran introduced a bill in the last Congress which conferred regulatory jurisdiction on the Interstate Commerce Commission in accordance with executive suggestion. ${ }^{13^{6}}$ The present S. 2 of the $75^{\text {th }}$ Congress is the same bill, amended and refined. However, recent developments in Washington have changed the whole picture again. In September, I937, the President appointed an Interdepartmental Committee, composed of representatives of the several executive departments, which was directed to study the legislation for the regu-

${ }^{132}$ Op. cit. supra note 5r, Recommendation No. ro2, and see discussion p. 342 et seq.

${ }^{133} I d$. at 244 .

${ }^{x 34}$ "The responsibility of allocating governmental aid among various claimants for consideration is too great to be allocated to any one individual or group of individuals that is part of the general machinery of the executive and subject to change with a change of popular favor as between contending political philosophies." Id. at 243 .

${ }_{335} I d$. at iv. The views of the President reflect the attitude of the Federal Coordinator of Transportation, Mr. Eastman, as shown in his reports: Regulation of Transportation Agencies, S. Doc. 5 52, 73d Cong. 2d Sess., and Report of the Federal Coordinator of Transportation, 1934, H. Doc. 89, 74th Cong. Ist Sess.

${ }^{136}$ S. $3027,74^{\text {th }}$ Cong. Ist Sess., defeated in the House. While the present Air Mail Law was in process, Sen. McCarran introduced a bill patterned after the recommendations of the Howell Commission. S. 3187,78 Cong. Rec. 5384 (1934), later defeated in the Senate when offered as an amendment (in the nature of a substitute) to the Black-McKellar Bill, $S_{3}$ I 70 , 78 Cong. Rec. $76 \mathrm{r}_{4}$ et seq. 
lation of aviation now before Congress and to recommend a legislative policy. ${ }^{\mathrm{x} 37}$ Although no report of this committee has been made public, it is understood from subsequent occurrences that an independent, executive commission for the regulation of all civil aeronautics was recommended. This Commission would be responsible to the executive, rather than Congress. After conferring with the President, the sponsors of the Lea-McCarran Bill are now redrafting the bill along the lines of an independent body. With White House support, this legislation should become law in early spring of 1938 .

As the bill now in process will undoubtedly resemble S. 2 in its major aspects, the administrative issue may appear relatively unimportant. Yet, if air transport is recognized as a legitimate part of the national transportation system, then it should be treated as part of the transportation problem. Co-ordination of all transportation agencies is the natural consequence of the present maladjustment. ${ }^{.38}$ Therefore, whatever form air transport regulation takes, its administrative structure should be patterned after the existing regulatory agency, the Interstate Commerce Commission. Only a legislative commission will lend itself to co-ordination and future consolidation into a unitary scheme.

Whether the airlines should remain under the control of the Interstate Commerce Commission, or be turned over to a new and independent body is not speedily answered. The Howell Commission, in I934, believed that an independent body was essential. ${ }^{.39}$ But the chief reasons assigned for this were that the Interstate Commerce Commission was not equipped to deal with the problems of aviation, and that the Commission was too occupied with more pressing matters. These objections have been demonstrated to be untrue. Opponents of the Motor Carrier Act of 1935 made the same objection to no avail. The charge that the Interstate Commerce Commission is "railroad minded" is patently false. ${ }^{\mathrm{x}^{\circ}}$ However, regulation by the Interstate Commerce Commission will bring into prominence the relation between air and rail carriers, who are becoming increasingly competitive for passenger traffic. With the duty to foster both agencies, it seems reasonable to say that the Interstate Commerce Commission will not fix the rates for air travel in such a way that rail revenues from passenger traffic will be unduly decreased. The shaky position of most railroads today warrants as much solicitude for them as for the younger and much smaller air carriers.

Recent experiments of the air carriers ${ }^{\mathrm{II}}$ have shown that the demand for air ${ }^{237}$ American Aviation (Oct. $x$, I937). The Committee included no member of the I.C.C. This omission was regarded as significant. American Aviation (Nov. 15, 1937).

${ }^{{ }_{3} 8}$ See Report of the Federal Coordinator, op. cit. supra note ${ }^{3} 35$; Moulton, The American Transportation Problem (I930).

${ }^{139} \mathrm{OP}$. cil. supra note 5I, at 243.

${ }^{140}$ See Air Mail Compensation, 206 I.C.C. 675 (r935) for careful analysis of problems of air transport.

${ }_{14}$ P. 490 silpra. 
travel is relatively elastic. A small decrease in fares may bring such an increase in traffic that the airlines would not be able to handle the business. But new air traffic is almost always former rail traffic. Realizing this, the Interstate Commerce Commission, in adjusting the rates of the two competing services, may tend to set the air tariffs higher than they otherwise would have been. How serious this might be is speculative as the total air traffic today is still less than 6 per cent of rail passengers in Pullmans alone. ${ }^{\mathrm{x} 2}$

The strongest argument in "favor of retention of control" by the Interstate Commerce Commission is that the commission has handled air transport for almost four years now, and, after much investigation and study, is in a position to deal with the problems promptly and realistically. The creation of an entirely new body means that another period of orientation must pass before the pressing problems can be disposed of. It is disadvantageous to both the government and the carrier to require him to tell his story all over again.

${ }^{24}$ Barney, op. cit. sutpra note 6 , at 44 . 